\title{
Assessment of genetic mutations by the gene's 5-httlpr and slc6a4 and scc6a4 in the human depression
}

\begin{abstract}
In this study we have analyzed 300 people. 140 Human depression and 160 control group. The genes 5-HTTLPR and SLC6A4 and SCC6A4 analyzed in terms of genetic mutations made. In this study, people who have genetic mutations were targeted, with nervous disorders, Human depression. In fact, of all people with Human depression, 114 people had a genetic mutation in the gene 5-HTTLPR. And 16 had a genetic mutation in SLC6A4 gene were a genetic mutation in the gene SCC6A4 and 10, respectively. Any genetic mutations in the target genes control group did not show.
\end{abstract}

Keywords: genetic study, cheating wives, mutation 5-httlpr, slc6a4, scc6a4 genes
Volume 2 Issue 2 - 2017

Shahin Asadi, Mahsa Jamali

Students of Molecular Genetics, Islamic Azad University, Iran

Correspondence: Shahin Asadi, students of Molecular Genetics, Islamic Azad University, Iran, Tel +989379923364, Email shahin.asadil985@gmail.com

Received: February 17, 2017 | Published: March 16, 2017

\section{Introduction}

Today, the love of marriage, are very important factor for survival is good and healthy. Every person with a sense of love can be permanently have a healthy lifestyle and good. Every person with a sense of love, can be found in all the hardships of life, feel fortunate. Since the genotypes of the human personality in control, so the sense of love of love gene, comply. ${ }^{1-3}$

Depression is a state of low mood and aversion to activity that can affect a person's thoughts, behavior, feelings, and sense of wellbeing. ${ }^{1,2}$ People with a depressed mood can feel sad, anxious, empty, hopeless, helpless, worthless, guilty, irritable, angry ${ }^{3,4}$ ashamed, or restless. They may lose interest in activities that were once pleasurable, experience loss of appetite or overeating, have problems concentrating, remembering details or making decisions, experience relationship difficulties and may contemplate, attempt or commit suicide. Insomnia, excessive sleeping, fatigue, aches, pains, digestive problems, or reduced energy may also be present. ${ }^{5}$ Depressed mood is a feature of some psychiatric syndromes such as major depressive disorder ${ }^{2}$ but it may also be a normal temporary reaction to life events such as bereavement, a symptom of some bodily ailments or a side effect of some drugs and medical treatments. A DSM diagnosis distinguishes an episode (or 'state') of depression from the habitual (or 'trait') depressive symptoms someone can experience as part of their personality. ${ }^{6}$

\section{Materials and methods}

This study, 140 case with Human depression and 160 controls were analyzed studied. Peripheral blood samples from patients and parents with written permission control was prepared. After separation of serum, using Real Time-PCR technique of tRNA molecules was collected. To isolate 5HTTLPR1A erythrocytes were precipitated from hydroxyethyl starch (HES) was used. At this stage, HES solution in ratio of 1 to 7 with the peripheral blood of cases and controls were mixed. After 90 minutes of incubation at room $37^{\circ} \mathrm{C}$ temperature, the supernatant was removed and centrifuged for $26 \mathrm{~min}$ at 560 Gera. The cells sediment with PBS (phosphate buffered saline), pipetajh and slowly soluble carbohydrate ratio of 1 to 7 on ficole (Ficol) was poured in the $680 \mathrm{G}$ was centrifuged for 51 minutes. 5HTTLPR1A gene also are included, has a lower density than ficole and soon which they are based. The remaining erythrocyte has a molecular weight greater than fico leand deposited in test tubes. ${ }^{7-9}$

The supernatant, which contained the mono nuclear cells was removed, and the 560 Gera was centrifuged for 62 minutes. Finally, the sediment cell, the antibody and 5HTTLPR1A cells was added after 44 minutes incubation at $8^{\circ} \mathrm{C}$, the cell mixture was passed from pillar LSMACS. Then the cells were washed with PBS and attached to the column LSMACSS pam Stem cell culture medium containing the transcription genes 5-HTTLPR, SLC6A4, SCC6A4 and were kept. ${ }^{10-13}$

To determine the purity of 5-HTTLPR, SLC6A4, SCC6A4 cells are extracted, flow cytometric was used. For this purpose, approximately 6-8 $\times 10^{3}$ 5-HTTLPR, SLC6A4, SCC6A4 cells were transfer red to $1.7 \mathrm{ml}$ Eppendorf tube and then was centrifuged at $6000 \mathrm{rpm}$ for 2 minutes at time. Remove the supernatant culture medium and there maining sediment, $200 \mu 1$ of PBS buffer was added. After adding 9-14 $\mu \mathrm{l} \mathrm{CD} 34^{+}$PE monoclonal anti body to the cell suspension for $40 \mathrm{~min}$ at $6^{\circ} \mathrm{C}$, incubated and readimme diately by flow cytometric. For example, rather than control anti body 5-HTTLPR, SLC6A4, SCC6A4 cells PE, IgG1 negative control solution was used. ${ }^{14-17}$

\section{Discussion and conclusion}

According to the results of sequencing the genome of cases with Human depression, and the genetic mutations 5-HTTLPR, SLC6A4, SCC6A4 genes found that about $89 \%$ of cases with Human depression, they have this genetic mutation. Cases with Human depression, unusual and frightening images in the process of Human depression, experience. Lot epigenetic factors involved in Human depression. But the most prominent factor to induce Human depression, mutations is 5-HTTLPR, SLC6A4, SCC6A4 genes. Despite the results of this study, but this cannot be documented for mutations to all human beings. Because epigenetic factors such as the life and thinking of every human being is different. The aim of this 
study was to understand the causes of divorce and infidelity, men and women in life than to be together. Since the character of all human beings to control their genotype, so no more prominent factor of DNA molecules to investigate abnormal behaviors of people there. We hope other researchers in this important study do more to get the results they understand the similarities and differences (Figures 1-7).

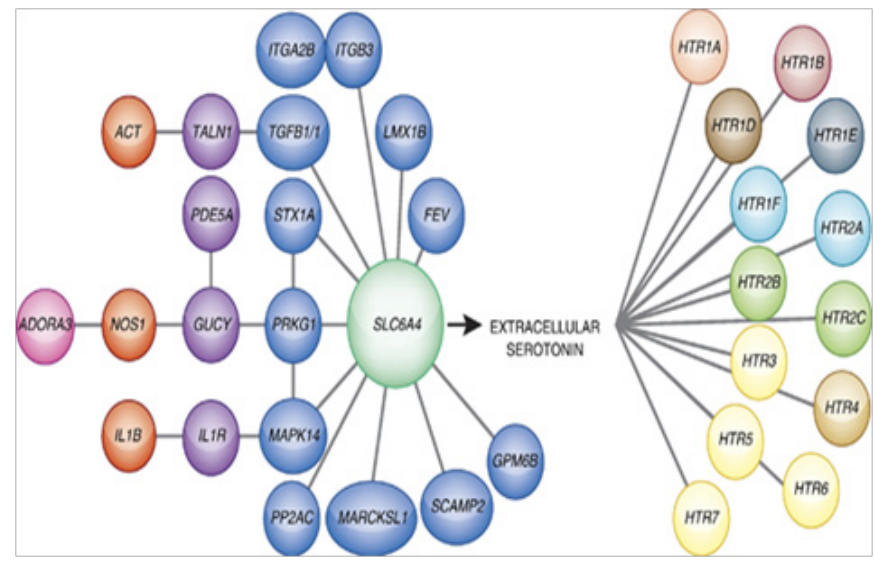

Figure I Schematic view of co-existence with other genes SLC6A4 gene and its corresponding.

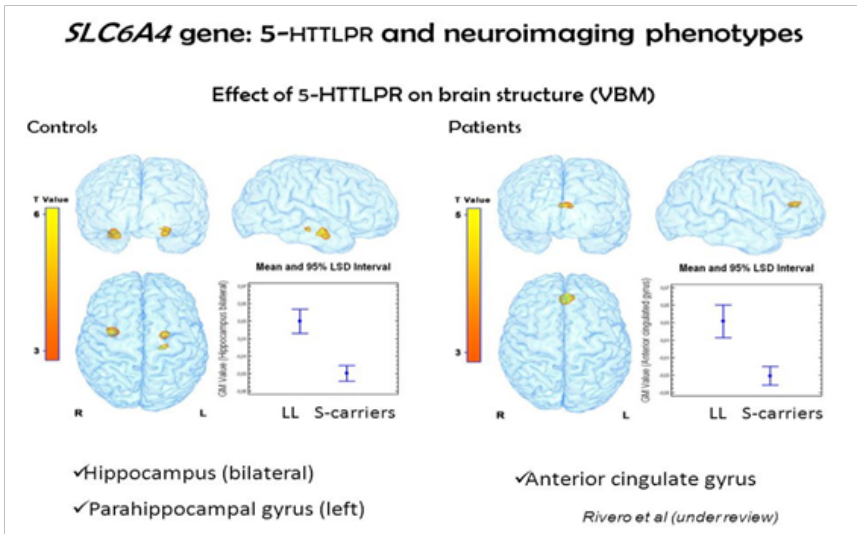

Figure 2 Schematic view of how the SLC6A4 and 5-HTTLPR gene effectiveness in different parts of the brain.

A

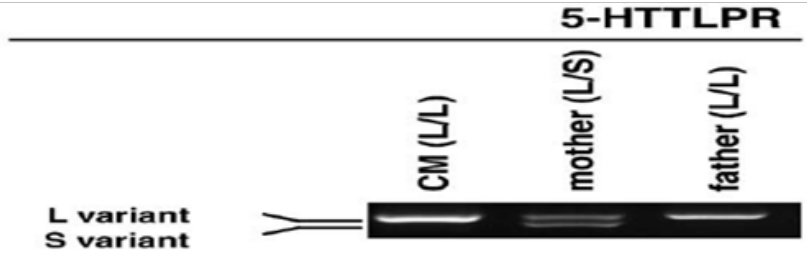

B

STIn2 VNTR

12 copies 10 copies

Figure 3 Schematic view of the pattern formed in the band gene 5-HTTLPR.
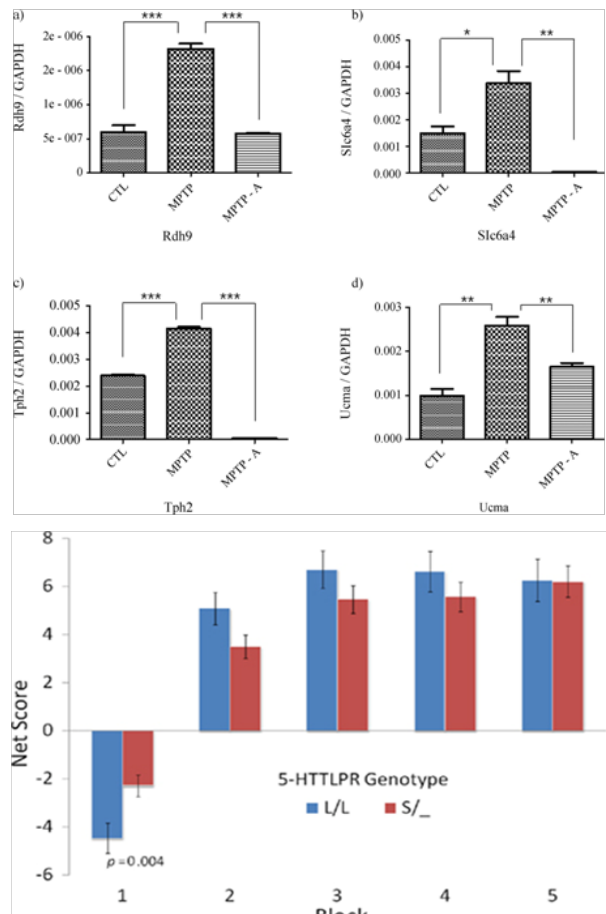

Figure 4 Schematic view of the diagram expression in gene 5-HTTLPR and SLC6A4.
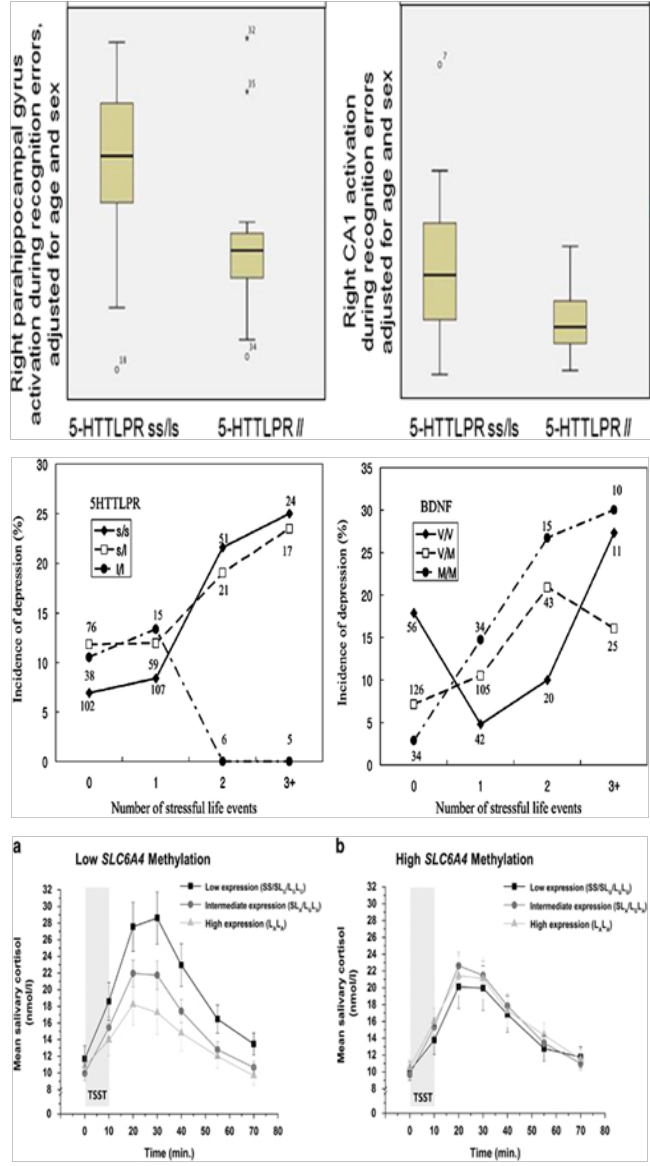

Figure 5 Schematic diagram graphing the activity of BDNF and 5-HTTLPR and SLC6A4 genes depression and betrayal of marital life. 


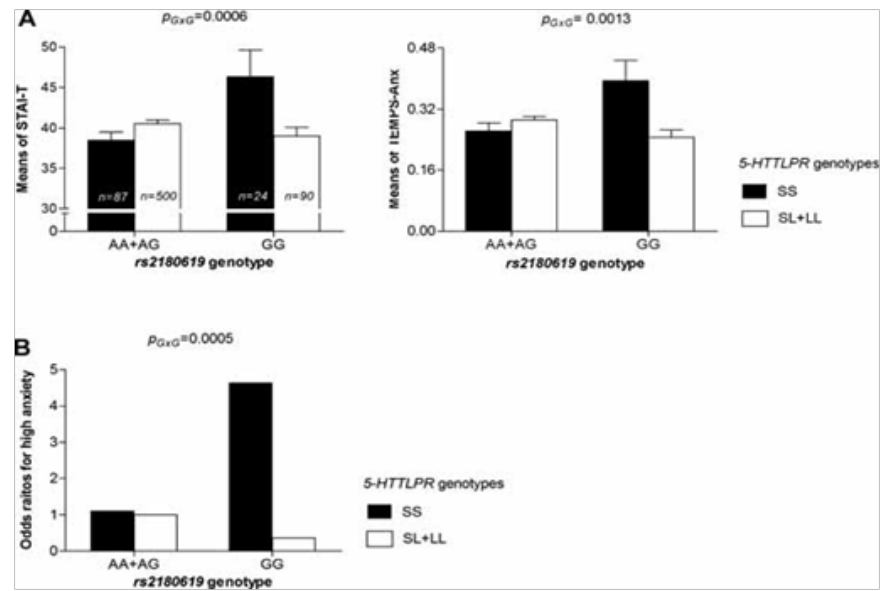

Figure 6 Schematic view of the diagram graphing the expression of gene 5 -HTTLPR polymorphisms in families studied and control group.

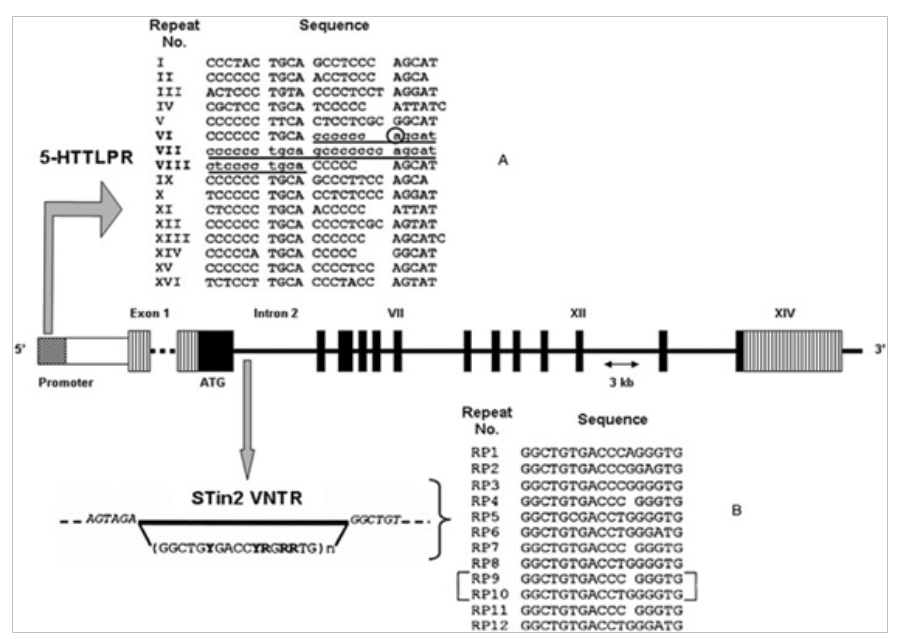

Figure 7 Schematic view of the nucleotide sequence of the gene 5-HTTLPR polymorphisms in families studied and control group.

\section{Acknowledgements}

This study written consent of men and women is studied. Thanks to everyone who helped us in doing this project, very grateful. Cases and their families also accepted cases that had very much for your cooperation in this study.

\section{Conflict of interest}

Author declares that there is no conflict of interest.

\section{References}

1. Heils A, Teufel S, Petri G, et al. Allelic variation of human serotonin transporter gene expression. Journal of Neurochemistry. 1996;66(6):2621-2624.

2. Nakamura M, Ueno S, Sano A, et al. The human serotonin transporter gene linked polymorphism (5-HTTLPR) shows ten novel allelic variants. Molecular Psychiatry. 2000;5(1):32-38.
3. Nicole Praschak-Rieder, James Kennedy, Alan A, et al. Novel 5-HTTLPR allele associates with higher serotonin transporter binding in putamen: a [(11) C] DASB positron emission tomography study. Biol Psychiatry. 2007;62(4):327-321.

4. Eisenberg DTA, Hayes MG. Testing the null hypothesis: comments on Culture-gene coevolution of individualism-collectivism and the serotonin transporter gene. Proceedings of the Royal Society $B$. 2011;278(1704):329-332.

5. Julien Mendlewicz, Isabelle Massat, Daniel Souery, et al. Serotonin transporter 5HTTLPR polymorphism and affective disorders: no evidence of association in a large European multicenter study. Eur J Hum Genet. 2004;12(5):377-372.

6. Caspi A, Sugden K, Moffitt TE, et al. Influence of Life Stress on Depression: Moderation by a Polymorphism in the 5-HTT Gene. Science. 2003;301(5631):386-389.

7. Kendler K, Kuhn J, Vittum J, et al. The interaction of stressful life events and a serotonin transporter polymorphism in the prediction of episodes of major depression: a replication. Arch Gen Psychiatry. 2005;62(5):529-535.

8. Munafo M, Durrant $\mathrm{C}$, Lewis $\mathrm{G}$, et al. Gene $\times$ Environment Interactions at the Serotonin Transporter Locus. Biological Psychiatry. 2009;65(3):211-219.

9. Katja Karg, Margit Burmeister, Kerby Shedden, et al. The serotonin transporter promoter variant (5-HTTLPR), stress, and depression metaanalysis revisited: evidence of genetic moderation. Archives of General Psychiatry. 2011;68(5):444-454.

10. Kathryn DL, Suzin M, Webb PM, et al. The serotonin transporter polymorphism, 5HTTLPR, is associated with a faster response time to sertraline in an elderly population with major depressive disorder. Psychopharmacology. 2004;174(4):525-529.

11. Jeffrey B Kraft, Susan L Slager, Patrick J McGrath, et al. Sequence analysis of the serotonin transporter and associations with antidepressant response. Biological Psychiatry. 2005;58(5):374-371.

12. Ball D, Hill L, Freeman B, et al. The serotonin transporter gene and peerrated neuroticism. Neuro Report. 1997;8(5):1301-1304.

13. Foxm E, Ridgewell A, Ashwin C. Looking on the bright side: biased attention and the human serotonin transporter gene. Proceedings of the Royal Society B. 2009;276(1663):1747-1751.

14. Shoshana Arbelle, Jonathan Benjamin, Moshe Golin, et al. Relation of shyness in grade school children to the genotype for the long form of the serotonin transporter promoter region polymorphism. American Journal of Psychiatry. 2003;160(4):671-676.

15. Ramin VP, Ramin S Hastings, Maria A Oquendo, et al. Effect of a Triallelic Functional Polymorphism of the Serotonin-Transporter-Linked Promoter Region on Expression of Serotonin Transporter in the Human Brain. The American Journal of Psychiatry. 2006;163(1):48-51.

16. Lukas Pezawas, Andreas Meyer-Lindenberg, Emily M Drabant, et al. 5-HTTLPR polymorphism impacts human cingulate-amygdala interactions: a genetic susceptibility mechanism for depression. Nature Neuroscience. 2005;8(6):828-824.

17. Ebstein RP. The molecular genetic architecture of human personality: beyond self-report questionnaires. Molecular Psychiatry. 2006;11(5):427-445. 